\title{
Cool roof technology in London: an experimental and modelling
} study

\author{
M. Kolokotroni ${ }^{\mathrm{a}}$, B.L. Gowreesunker ${ }^{\mathrm{a}}$, R. Giridharan ${ }^{\mathrm{b}}$ \\ ${ }^{a}$ Howell Building, Mechanical Engineering, School of Engineering and Design, Brunel University, \\ Uxbridge, Middlesex, UB8 3PH, UK \\ ${ }^{b}$ Civil and Building Engineering, Loughborough University, Leicester, LE11 3TU, UK
}

\begin{abstract}
One of the primary reasons for the application of cool materials is their energy and associated environmental impact on the built environment. Cool materials are usually applied on the roof of buildings to reduce cooling energy demand. The relative benefits of this reduction depend on the construction of the building, external weather conditions and use of the building. This paper examines the impact from the application of a reflective paint on a flat roof in a naturally ventilated office building in the area of London, UK where the climate is moderate with high heating demand by buildings. The environmental conditions (internal/external air and surface temperatures) of the building were monitored before and after the application of the cool roof during the summer. It was found that internal temperatures were reduced after the application of the cool roof. The building was modelled using TRNSYS and the model was calibrated successfully using the measurements. A parametric analysis was carried out by varying the reflectivity and insulation of the roof and ventilation rate; the heating and cooling demand for a year was calculated using the Summer Design Year for London as the weather file. It was found that cooling demand is significantly reduced, heating demand is increased and the total energy savings vary between 1 and $8.5 \%$ relative to an albedo of 0.1 for the same conditions. In free floating (naturally ventilated) buildings summer comfort is improved but there is a penalty of increased heating energy during the winter. Thermal comfort can be improved by an average of $2.5{ }^{\circ} \mathrm{C}$ (operative temperature difference for a change of 0.5 in albedo) but heating demand could be increased by $10 \%$ for a ventilation rate of 2 air changes per hour. The results indicate that in the case of temperate climates the type, operation and thermal characteristics of the building should be considered carefully to determine potential benefits of the application of cool roof technology. For the examined case-study, it was found that a roof reflecticity of 0.6-0.7 is the
\end{abstract}


optimum value to achieve energy savings in a cooled office, improve summer internal thermal conditions in a non-cooled office (albeit with some heating energy penalty). It indicates that it is a suitable strategy for refurbishment of existing offices to improve energy efficiency or internal environmental conditions in the summer and should be considered in the design of new offices together with other passive energy efficient strategies.

\section{INTRODUCTION}

Rejection of solar gains is the aim of passive cooling strategies in any type of building and any climatic region. This needs to be balanced with admission of solar heat gains which is beneficial for all building types and climatic conditions; the extent of usefulness is dependent on severity of external conditions and internal heat gains.

Cool materials work by reflecting solar radiation and therefore rejecting solar heat gains at the opaque external surfaces of the building. Heat transfer to the internal space by conduction is therefore reduced; the magnitude of the reduction will be determined by:

- The magnitude of solar radiation

- The different of air and surface temperature between outside and inside of the building

- The construction of the opaque building element, namely its resistance to heat transfer.

A number of experimental and computational studies have been carried out to demonstrate the energy benefits of cool roofs in reducing energy demand in buildings in cooling dominated climates. A number of papers have been published for residential buildings [1, 2, $3,4,5,6]$, retail stores [7], and other commercial buildings [8,9]. Work has also been carried out outside the US. A modelling study [10] has shown the benefits in retail store at different climates. Cool Roofs have also been studied in experimental facilities; [11, 12].

Experimental and computational studies are less numerous for buildings located in climates with moderate cooling demand because in many cases the heating penalties can out-weight cooling benefits. However, there are net energy benefits to be obtained; in particular cool 
roofs can improve internal thermal comfort in buildings without air-conditioning. Therefore, they could be considered despite heating energy penalties as they can help avoidance of airconditioning installation.

Akbari and Konopacki [13] have presented an excellent summary of results to 2004 in the US for both hot and cold regions. Computational studies were carried out to estimate the net direct energy savings (cooling-energy savings minus heat-energy penalties) from reflective roofs on residential and commercial buildings in 11 US metropolitan statistical areas (MSAs). Metropolitan-wide savings were as much as \$37 $\mathrm{M}$ for Phoenix and \$35 $\mathrm{M}$ in Los Angeles and as low as $\$ 3 \mathrm{M}$ in the heating-dominated climate of Philadelphia.

The same paper [13] presented results for Toronto, Canada. It showed that by increasing the albedo of houses by 0.2 (from moderate-dark to medium-light colour), the cooling-energy use can be reduced by about $30-40 \%$. However, they also found that reflective roofs and shade trees reduce summer cooling-energy use and also potentially increase winter heatingenergy use.

A numerical study performed by Shariah et al [14] for the moderate climate of Amman and the hot climate of Aqaba, in Jordan, showed that by increasing the external reflectance of the roof from 0 to 1 , the energy load reduces by $32 \%$ for a non-insulated building and $26 \%$ for an insulated building in Amann. Higher energy savings are obtained for Aqaba. Synnefa et al [1] numerically found for various climatic conditions around the world that by increasing the roof albedo by 0.65 , cooling reductions of $9-48 \mathrm{kWh} / \mathrm{m}^{2}$ were obtained, with heating penalties in the range of $0.2-17 \mathrm{kWh} / \mathrm{m}^{2}$. Furthermore, they concluded that the two most influential factors for the performance of roof reflective coatings are the U-value of the roof and the climatic conditions. Akbari et al [8] conducted experimental and numerical studies for 16 Californian climate zones, and reported energy savings of about $4.5-7.4 \mathrm{kWh} / \mathrm{m}^{2}$ of conditioned roof area per year. They also differentiated between the investigated buildings, signifying the importance of building operation on the performance of roof reflective coatings.

There is recent interest in the UK's moderate climate on the benefits of Cool Roofs and an Information Paper was published recently on this [15] arguing that net savings are also 
obtainable in the UK climatic conditions, with the benefits decreasing with enhanced insulation, lower operating temperatures or increase in internal gains.

In this context, the present paper reports results of work carried out within the framework of the EU project "Cool Roofs" which aims to develop and implement an action plan for the promotion of Cool Roofs in European countries (www.coolroofs-eu.eu). Part of the project is the implementation of five demonstration projects, as shining examples of Cool Roofs' capabilities in improving the thermal conditions and reducing the energy consumption in buildings. The case studies were monitored, in regard to their energy performance and indoor environment, before and after the implementation of a cool roof technology. The buildings were selected to achieve maximum geographical and building typology coverage aiming to promote the benefits coming from this technique with reference to cooling energy demand and peak savings all around the EU. The corresponding activities were performed at two levels:

- experimental monitoring in real buildings treated with Cool Roof techniques (hardware task)

- numerical analysis of the same buildings with a number of variants (software analysis)

In general, the findings of the case studies show $10-40 \%$ energy savings and $1.5-2^{\circ} \mathrm{C}$ reduction of the indoor temperatures, depending on the climatic conditions [16]. The selected case studies are (a) a school building in Kaisariani, Greece, (b) a laboratory building in the Chania, Crete - Greece, (c) a dwelling in Poitiers, France, (d) a public building (mixed office and laboratory) in Trapani, Italy and (e) an office building in London, United Kingdom (UK). Following the methodology developed by the CoolRoofs Project [16], this paper reports results of the UK case-study. First a description of the building is presented (section 2), followed by an analysis of the measured data before and after the application of a cool roof (section 3). In section 4, the development and calibration of a building model of the casestudy is presented, together with the results of a parametric computational analysis to determine the range of application and benefits of cool roofs in offices in London, UK. Measured data were used to calibrate the computational model to improve confidence on its predictions. Summary of results and conclusions are presented in section 5. 


\section{DESCRIPTION OF THE BUILDING AND COOL ROOF TECHNOLOGY}

The case-study is the estates office at Brunel University and consists of one open office area and three separate office rooms. It is located on the top floor (flat roof) of a four storey building of which the top floor was constructed in 1995 . The total floor area is $137 \mathrm{~m}^{2}$ of which the open office area accounts for $97.6 \mathrm{~m}^{2}$. The floor to ceiling height is approximately $2.65 \mathrm{~m}$. The open office area has 6 window openings while each room has one opening. Each of these openings is approximately $0.9 \mathrm{~m} \times 1.5 \mathrm{~m}$. The office has work space for about 15 people but on most occasions there will be about 10 to 13 working at a time, each provided with a computer.

A survey was carried out to determine the construction details of the roof and walls. The roof is made of $0.15 \mathrm{~m}$ thick concrete slab with a $0.04 \mathrm{~m}$ insulation layer on top of the slab and is covered with a layer of water proofing material (asphalt). During the second part of the experimental period, the cool roof material was applied on top of the asphalt. The external wall structure is made of $0.125 \mathrm{~m}$ thick concrete block work and is protected with $0.18 \mathrm{~m}$ insulation layer and $\mathrm{ZnAl}$ cladding. The floor is made of $0.15 \mathrm{~m}$ thick concrete slab laid with synthetic carpet. All the internal walls are made of dry wall partition. The office has a central heating system with perimeter radiators and is naturally ventilated through openable windows. The windows are fitted with horizontal window blinds. Figure 1 shows the floor plan and an internal photo of the open plan office and Table 1 summarises the characteristics of the external envelope of the case-study.

The properties of the roof surface relevant to the study of this paper are two; (a) Solar reflectance (SR) or albedo is a measure of the ability of a surface material to reflect solar radiation. The term solar reflectance (SR) designates the total reflectance of a surface, considering the hemispherical reflectance of radiation, integrated over the solar spectrum, including specular and diffuse reflection. It is measured on a scale of 0 to 1 (or $0-100 \%$ ) and (b) Infrared emittance $(\varepsilon)$, is a measure of the ability of a surface to release, absorbed heat. It specifies how well a surface radiates energy away from itself as compared with a black body operating at the same temperature. Infrared emittance is measured on a scale from 0 to 1 (or $0-100 \%)$.

The pre-painted building was monitored (roof albedo value 0.1) for two months (May to June 2009); a cool roof paint was applied in July and monitoring continued for another two months 
(August-September 2009). The cool roof paint was selected from ABOLIN (Cool Barrier 012 - CB012) with an SR value of 0.7 and infrared emittance of 0.88 [17]. After the application, in-situ albedo measurements were carried out and the measured SR value found to be 0.6 which is the value used in the simulations. Figure 2 presents an external photo of the building together with the spectral characteristics of the cool roof material.

\section{MONITORING PROCEDURE AND RESULTS}

The study measured internal ceiling (slab) surface temperature, indoor air temperature, indoor relative humidity and roof surface temperature. Further, indoor air temperature and relative humidity of room below was also measured. The indoor air temperature and relative humidity was measured at 6 locations while internal ceiling temperature was measured at 3 locations as shown in Figure 3. Hobo loggers and thermocouples were used for data acquisition. The data was recorded at $10 \mathrm{~min}$ interval. The roof thermocouple was protected from direct solar radiation with rock wool and then applying cement plaster, painted white. Internal surface temperature measurement thermocouples are fixed to the ceiling using black sticky tape.

Formal measurement for pre-application of cool paint started on $1^{\text {st }}$ of May 2009 and ended on $1^{\text {st }}$ week of July 2009. From second week of July 2009 to last week of July was utilised for preparation and painting of cool roof paint. The post painting period covers $1^{\text {st }}$ August 2009 to $30^{\text {th }}$ September 2009 . Figure 4 presents measured air and surface temperatures in June and August 2009 where the trend lines indicate that roof surface temperature is lower in August (after paint period). Figure 4 presents almost raw data to give an indication of the measured data and their evolution; average solar radiation during day time was higher in June (average of $295 \mathrm{~W} / \mathrm{m}^{2}$ ) than in August (average of $268 \mathrm{~W} / \mathrm{m}^{2}$ ) while average external temperature was lower in June (average of $17^{\circ} \mathrm{C}$ ) compared to August (average of $18.4{ }^{\circ} \mathrm{C}$ )

In order to give a further insight of the pre and after cool roof application conditions, measurements on two days are presented in Figure 5. The first day is before application and the second day after the application; both days have very similar external average temperature $\left(19.5{ }^{\circ} \mathrm{C}\right.$ on 1 June and $19.0{ }^{\circ} \mathrm{C}$ on 16 August $)$ and average global solar radiation during daytime $\left(351 \mathrm{~W} / \mathrm{m}^{2}\right.$ on 1 June and $350 \mathrm{~W} / \mathrm{m}^{2}$ on 16 August). Roof surface temperature and internal ceiling surface temperature was higher on the 1 June compared to 
16 August . Roof surface temperature was higher by a maximum of $7.7{ }^{\circ} \mathrm{C}$ and an average of $6{ }^{\circ} \mathrm{C}$ during working hours (7.00-17.00). Ceiling surface temperature was higher by a maximum of $3.1{ }^{\circ} \mathrm{C}$ on 1 June and an average of $3.1{ }^{\circ} \mathrm{C}$ during working hours. In Figure 5 , a slight decrease in the ceiling surface temperature can be observed on both days between 7-8 am (more marked in 1 June) due to increased ventilation rate by users' opening of windows as they come to the office. Results of analysis taking into account operation of the building and external weather conditions are presented in the following paragraphs.

Hourly measurements were analysed and in this paper, we present the daytime trend analysis results focussing on normal operational times of the office, i.e. 7:00 hrs to 17:00hrs, and limit its boundary to the open office area since this is the area that houses the bulk of the staff (more than $70 \%$ ) and activities.

Surface temperature differences were calculated by deducting internal ceiling surface temperature from roof surface temperature. This discounted mean hourly surface temperatures of pre painted period shows that during early morning and evening, the roof is cooler than internal ceiling while during mid day the opposite occurs (Figure 6). However during post painted period internal ceiling surface temperatures are always higher than roof surface temperature indicating the cooling effect of cool paint on external roof surface.

Air temperature differences were calculated by deducting Heathrow (from where the climatic data are collected) air temperature from the respective indoor air temperature. This discounted air temperature shows that the open office is cooler by $2.7^{\circ} \mathrm{C}$ after applying cool paint (Figure 7). This analysis considers all data before and after application of cool roof paint. However, there are some difference in the external climate; there is a drop in mean solar radiation intensity in the order of $124 \mathrm{~W} / \mathrm{m}^{2}$ which is substantial considering the UK climate. Further, large part of the post painted period falls within cloudy and partially cloudy. Therefore further controlled analysis is required to estimate the influence of cool paint on reduction of surface temperature.

A climate control analysis was carried out which classifies the data into clear sky, partially cloudy and cloudy considering solar radiation intensity and cloud cover. This classification is based on findings of [18]. Where there is a conflict between solar radiation intensity and 
cloud cover classification, the decision will be based on solar radiation intensity for day time analysis while cloud cover for night time [19].

The controlled surface and air temperature trends show that both, before and after painting, cloudy and partially cloudy periods are close to clear sky days. This indicates the usage of heating system and/or changes in the ventilation rate during cloudy and partially cloudy periods. Therefore, in this scenario, partially cloudy and cloudy period data may not suitable to investigate the direct impact of the cool roof paint.

The controlled air temperature shows that after applying cool paint, the open office is on an average cooler by $1.9,1.8$ and $1.7{ }^{\circ} \mathrm{C}$ during cloudy, partially cloudy and clear sky periods respectively (Figure 8). During clear sky periods, under both pre-painted and post painted periods, outdoor climate is almost similar while the internal activities and occupancy too have remained same (observed through continuous monitoring). Further mean albedo of roof increased by 0.45 after applying cool paint (Table 2). Therefore the reduction of air temperature in the order of $1.7{ }^{\circ} \mathrm{C}$ in the open plan office could be directly attributed to cool paint. This reduction occurs during clear sky periods during which solar radiation is higher than $500 \mathrm{~W} / \mathrm{m}^{2}$ and cloud cover is less than 4 octas.

Field studies can only give an indication of the benefits of a technology and are restricted by the case-study parameters, in particular in an operational building. For example, in Figure 8, a drop of temperature can be seen at 9.00am for the case of 'clear sky after'. This is probably because, the internal temperature was high for comfort in the morning when the user came in an the windows were opened for rapid ventilation; then it because too draughty and windows were adjusted. Also, during early morning data points are fewer for the 'clear sky' climate control case. Therefore, the paper continues with a computational study which examines a range of parameters related to the operational and thermal characteristics of office buildings in London. In order to increase confidence on the prediction results, a model of the casestudy building was created as close as possible to the real building. The prediction results were compared with measurements to create a calibrated model of the case-study office. The modelling procedure, calibration and parametric analysis results are presented in the following section 4. 


\section{MODELLING PROCEDURE, CALIBRATION AND RESULTS}

Thermal modelling was carried out using TRNSYS [20]. Firstly, the model was built in terms of construction, internal heat gains and ventilation/infiltration as close to the observed reality as possible. The building is a naturally ventilated building controlled by the occupants; therefore reasonable assumptions were made for ventilation and infiltration as well as internal heat gains. These were verified with observations during the monitoring period. Weather data for the simulation was sourced from Heathrow meteorological station which is in the proximity of Brunel University.

The building was modelled as one zone (the open plan office). Simulations were run and operational details of the model were changed until the minimum (or optimal) accepted error for a building of this nature was achieved. Calibration concentrated on two months, June and September. June was the month before the application of the paints and thus the solar absorptance of the roof was set to 0.9; September was the month after the application of the paint and the solar absorptivity of the roof was set to 0.4. (consistent with the average value from albedo measurements-Table 2). September was chosen for the calibration study because ooperation of the office was nearer to normal as August is the traditional holiday month in the UK; therefore occupancy and other internal heat gains linked to occupancy patterns are more consistent in September and more comparable to June.

The operational and internal heat gains details as specified for the final calibration are as shown in Table 3. The only difference of the June and September models are in the roof's solar absorptance and also the ventilation rate. External air temperature in June was higher than September and this has led to variations in opening/closing windows which has affected the ventilation rate; in addition driving forces for infiltration were lower and therefore this had an impact on the infiltration rate.

Figure 9 presents a comparison of measured and predicted ait temperatures which are within a $10 \%$ error band. The case study is a naturally ventilated building and therefore it is very difficult to adjust the ventilation rate daily. For the main modelling exercise, these values will be set to some reasonable values differentiating between winter and summer. As the purpose of the modelling is to compare the building with and without cool roof, it is the relative difference which is important and therefore the accuracy of the absolute values is 
secondary as long as sensible parameters are specified derived from the results of this calibration.

After the calibration of the model was satisfactory, further simulations were carried out using the DSY (Design Summer Year) Heathrow weather file for external conditions. For this analysis, the June model was used for the comparison of modelling results. The difference of the two models (without cool roof and with cool roof) is in the solar reflectance value of the external layer of the roof construction. Absorbtivity is taken as 0.9 (albedo 0.1) for without cool roof and 0.4 (albedo 0.6) for with cool roof, which implies a difference of 0.5 in the reflectivity value. Summer simulations were run (summer is taken as the five months of May to September) and the air and operative temperature during working hours (7.00-18.00) are shown in Table 4.

It can be seen that in all cases air temperature during the summer months is reduced by the application of the cool roof. Taking the month of July as an example max internal air temperature is reduced by $1.3{ }^{\circ} \mathrm{C}$ and average air temperature by $2.1{ }^{\circ} \mathrm{C}$; this compares favourably with monitoring results analysis which shows a drop in air temperature of about $1.7{ }^{\circ} \mathrm{C}$ (section 3). In terms of thermal comfort, max operative temperature is reduced by 2.2 ${ }^{\circ} \mathrm{C}$ and average operative temperature by $2.5^{\circ} \mathrm{C}$ improving significantly thermal comfort.

The predicted hours of internal air and operative temperature above $25{ }^{\circ} \mathrm{C}$ and $28^{\circ} \mathrm{C}$ are presented in Table 5; it can be seen that these are reduced significantly with increased albedo.

The heating and cooling loads for maintaining the building at $21^{\circ} \mathrm{C}$ in winter and $25^{\circ} \mathrm{C}$ in the summer for two rates of ventilation rate were simulated for the building before and after the application of the cool roof. The results are presented in Table 6 in $\mathrm{kWh} /$ year for the whole case study space which has a floor area of $97.6 \mathrm{~m}^{2}$.

As expected heating demand has increased and cooling demand has decreased with the cool roof. Overall, a slight decrease in energy demand is predicted. However, it also indicates a higher heating demand for the building which is naturally ventilated (no cooling) but with improved comfort during the summer. 


\section{PARAMETRIC ANALYSIS}

A parametric analysis was carried out using the case study as the reference building. The following parameters were considered:

1. Albedo was changed in the range of 0.1-1.0 and the overheating hours during the summer (May to September) were calculated.

2. Set-point temperature was varied for winter and summer and the heating and cooling demand was calculated for albedo values in the range of 0.1-1.0 for ventilation rate of 2 and $4 \mathrm{ACH}$. The set point temperatures considered are 21 and $23{ }^{\circ} \mathrm{C}$ in winter and 23 and $25^{\circ} \mathrm{C}$ in the summer.

The results of the calculated overheating hours during summer for albedo range 0.1-1.0 are presented in Figure 10. Internal air and operative temperatures are presented above 25 and 28 ${ }^{\circ} \mathrm{C}$. The internal comfort is improved with higher albedo values. Comfort (temperatures above $25{ }^{\circ} \mathrm{C}$ ) is improved for $25 \%$ hours in terms of internal air temperature by changing the albedo from 0.1 to 0.9 while operative temperature is improved for $30 \%$ of the hours.

The results for the cooling loads for the two set-point summer internal air temperatures are presented in Figure 11 for albedo values varying between 0.1-1.0. The cooling load is shown as a percentage demand compared with albedo of 0.1. Similarly, Figure 12 presents the heating loads for varying albedo. Figures 13 and 14 show the total heating and cooling load for combination of set point temperature again as a percentage demand compared with albedo of 0.1 . The cooling demand is reduced significantly for all operating conditions with increased albedo but the balance follows different patterns.

Figures 13 and 14 indicate that building parameters (air change rate and set point temperatures) are important in the balance of heating and cooling demand for the building. In general, there is a reduction of heating and cooling demand and this varies between $1 \%$ and $8.5 \%$ during the year. As expected, lower ventilation rates achieve higher energy savings in an air-conditioned building with the highest reduction indicated (for the examined case) for an albedo value of 1.0 (but a lower value should be considered for pragmatic reasons), air change rate of 2 and summer and winter set-point temperatures of $25{ }^{\circ} \mathrm{C}$ and $21{ }^{\circ} \mathrm{C}$ respectively. 
Finally, a study was carried out by changing the insulation level of the roof. This is because as demonstrated in other work mainly concerned with hot climates [1], an increase in the insulation of the roof will decrease the cooling potential of the cool roof because of heat transfer reduction. This was investigated in the present study by changing the U-value of the case-study building roof from 0.23 to $1.88 \mathrm{~W} / \mathrm{m}^{2} \mathrm{~K}$ (U-value of original roof was 0.6 ) by changing the thickness of the insulation. Simulations were run for albedo values of 0.1 and 0.7. The results are presented in Figure 15 which indicates that there exist higher potential energy savings if roof albedo values are higher and insulation levels lower. For example, the potential savings are $1.67 \mathrm{kWh} / \mathrm{m}^{2}$ roof area with a change of albedo from 0.1 to 0.7 and roof $\mathrm{U}$-value of $0.23 \mathrm{~W} / \mathrm{m}^{2} \mathrm{~K}$ while the potential savings are $5.75 \mathrm{kWh} / \mathrm{m}^{2}$ roof area with a change of albedo from 0.1 to 0.7 and roof $\mathrm{U}$-value of $1.88 \mathrm{~W} / \mathrm{m}^{2} \mathrm{~K}$. As mentioned before this is consistent with studies in other countries [1] but the magnitude of savings is lower in London due to climatic conditions.

\section{SUMMARY OF RESULTS AND CONCLUSIONS}

Under the EU CoolRoofs project, a case-study building was set-up in London UK, to examine the energy benefits of cool roof technology by measurement and simulation. The building is located at Brunel University, west London and is an open plan office on the top floor of a four storey building. Air and surface temperature measurements were recorded in $10 \mathrm{~min}$ intervals and averaged to hourly intervals. As the monitored period cover different parts of the year it is difficult to make firm conclusions but a reduction in internal and external surface temperatures as well as external surface temperatures was observed. Analysis was carried out by considering internal/external temperature differences and was found that:

- Surface temperature were reduced by an average of $2{ }^{\circ} \mathrm{C}$ in the middle of the day

- Air temperatures were reduced by an average of $2-3{ }^{\circ} \mathrm{C}$ in the middle of the day

In order to study the effect in more detail, thermal simulations were carried out using TRNSYS. For confidence in using the model, an extensive calibration phase took place; measured temperatures before and after the application of the cool roof were compared to simulation results. Simulations were carried out using a weather file with actual conditions during summer 2009. As expected, in the case of a free-floating building, air flow rate 
through open windows was the most difficult parameter to estimate; internal gains through people and equipment was found easier to estimate. Despite the difficulties, a model was arrived at which includes realistic estimates of the building operational schedule and compares reasonably well with the measurements; agreement is taken as satisfactory when average daily (working hours) temperature is predicted within $10 \%$ of measured temperature. This has been achieved over the summer season; more close agreement would have been possible if variable air flow rate was applied.

TRNSYS simulations have indicated the following:

1. There is reduction on maximum and average internal air and operative temperatures during the summer months. For the month of July, maximum internal air temperature is reduced by $1.3{ }^{\circ} \mathrm{C}$ and average air temperature by $2.1{ }^{\circ} \mathrm{C}$. In terms of thermal comfort, max operative temperature is reduced by $2.2{ }^{\circ} \mathrm{C}$ and average operative temperature by $2.5{ }^{\circ} \mathrm{C}$ improving significantly thermal comfort. Albedo values were taken as 0.1 (before cool roof ) and 0.6 (after cool roof).

2. Overheating hours during the summer have been reduced significantly with higher albedo values. Comfort (temperatures above $25{ }^{\circ} \mathrm{C}$ ) is improved for $25 \%$ of hours in terms of internal air temperature by changing the albedo from 0.1 to 0.9 while operative temperature is improved for $30 \%$ of the hours.

3. Heating load was increased and cooling load was decreased with an overall reduction. The overall energy demand reduction is between 1 and $8.5 \%$ relative to an albedo of 0.1 for the same conditions. As expected, lower ventilation rates achieved higher energy savings in an air-conditioned building with the highest reduction indicated (for the examined case) for an albedo value of 1.0, air change rate of 2 and summer and winter set-point temperatures of $25^{\circ} \mathrm{C}$ and $21{ }^{\circ} \mathrm{C}$ respectively.

4. Considering realistic values for albedo, the optimum albedo is indicated as 0.6 to 0.7 with air change rate of $2 \mathrm{ACH}$ which achieved an overall heating and cooling load reduction of 3-6\% depending on the set-point temperature.

5. Increasing insulation levels would decrease potential energy benefits in heating and cooling demand. For a U-value of $1.88 \mathrm{~W} / \mathrm{m}^{2} \mathrm{~K}$ a change of albedo from 0.1 to 0.7 would reduced the heating and cooling demand by $7 \%$ while for a U-value of 0.23 $\mathrm{W} / \mathrm{m}^{2} \mathrm{~K}$, the same change of albedo will reduce the load by only $2 \%$. 
In conclusion this case-study analysis for the moderate climate of South East England (suburban London) indicates that applying cool roof technology could be beneficial in terms of increased thermal comfort in the summer and could decrease overall energy use for heating and cooling. However, energy savings are dependent on building related construction and operation. In general:

- In free floating (naturally ventilated) buildings summer comfort is improved but there is a penalty of increased heating energy during the winter. Thermal comfort can be improved by as much as $2.5{ }^{\circ} \mathrm{C}$ (operative temperature difference for a change of 0.5 in albedo) but heating demand could be increased by $10 \%$.

- In air conditioned buildings, set-point temperature plays an important role in the comparative energy demand for the range of albedo values. In general, there is a reduction of heating and cooling demand and this varies between $1 \%$ and $8.5 \%$ during the year. As expected, lower ventilation rates achieve higher energy savings in an air-conditioned building with the highest reduction indicated (for the examined case) for an albedo value of 1.0, air change rate of 2 and summer and winter setpoint temperatures of $25{ }^{\circ} \mathrm{C}$ and $21{ }^{\circ} \mathrm{C}$ respectively.

- Insulation level of the roof will affect the reduction in heating and cooling energy demand with decreasing benefits for higher insulation values.

Considering realistic values for albedo, the optimum albedo is indicated as 0.6 to 0.7 with air change rate of $2 \mathrm{ACH}$ which achieved an overall heating and cooling load reduction of 3-6\% depending on the set-point temperature. Energy benefits are higher for lower insulation of the roof.

\section{ACKNOWLEDGMENTS}

This work was carried out as part of the project CoolRoofs Contract $\mathrm{N}^{\circ}$ : EIE/07/475/SI2.499428 funded by the Intelligent Energy Europe (IEE) program SAVE 2007. 


\section{LIST OF REFERENCES}

1. Synnefa A, Santamouris M, Akbari H, (2007). Estimating the effect of using cool coatings on energy loads and thermal comfort in residential buildings in various climatic conditions, Energy and Buildings 39, 1167-1174.

2. Levinson R, Akbari H, Reilly JC. (2007). Cooler tile-roofed buildings with near-infraredreflective non-white coatings, Building and Environment 42, 2591-2605

3. Zinzi M, Fasano G. (2009). Properties and performance of advanced reflective paints to reduce the cooling loads in buildings and mitigate the heat island effect in urban areas. International Journal of Sustainable Energy. Vol. 28, Nos. 1-3, 123-139

4. Suehrcke H, Peterson EL, Selby N. (2008). Effect of roof solar reflectance on the building heat gain in a hot climate. Energy and Buildings 40, 2224-2235

5. Akbari H, Bretz S, Kurn D, Hanford J. (1997). Peak power and cooling energy savings of high-albedo roofs. Energy and Buildings; 25, 117-26.

6. Parker D, Huang J, Konopacki S, Gartland L, Sherwin J, Gu L. (1998). Measured and simulated performance of reflective roofing systems in residential buildings. ASHRAE Trans;104(1), 963-75.

7. Konopacki S, Akbari H. (2001). Measured energy savings and demand reduction from a reflective roof membrane on a large retail store in Austin. Report LBNL-47149.

Berkeley, CA: Lawrence Berkeley National Laboratory.

8. Akbari H, Levinson R, Rainer L. (2005), Monitoring the energy-use effects of cool roofs on California commercial buildings, Energy and Buildings, 37. 1007-1016

9. Jo JH, Carlson JD, Golden JS, Bryan H, (2010). An integrated empirical and modeling methodology for analyzing solar reflective roof technologies on commercial buildings, Building and Environment, 45, 453-460

10. Wang X, Kendrick C, Ogden R, Maxted J. (2008). Dynamic thermal simulation of a retail shed with solar reflective coatings. Applied Thermal Engineering 28, 1066-1073

11. Cheng V, Ng E, Givoni B. (2005). Effect of envelope colour and thermal mass on indoor temperatures in hot humid climate Solar Energy 78, 528-534

12. Yu B, Chen Z, Shang P, Yang J, (2008). Study on the influence of albedo on building heat environment in a year-round, Energy and Buildings 40, 945-951

13. Akbari H, Konopacki S, (2004). Energy effects of heat-island reduction strategies in Toronto, Canada. Energy 29, 191-210 
14. Shariah A, Shalabi B, Rousan A, Tashtoush B (1998), Effects of Absorptance of external surfaces on heating and cooling loads of residential buildings in Jordan, Energy Conversion and Management 39(3/4): 273-284.

15. Halewood J, De Wilde P (2010), Cool Roofs and their applications in the UK, IP 13/10, BRE, Garston.

16. Zinzi M (ed), (2010). Report on the five case studies and analysis of the results, Cool Roofs EU project, available from www.coolroofs-eu.eu

17. Abolin technical report, (2008) (http://www.abolincoolpaints.com/node/63

18. Kolokotroni, M., Giridharan, R., (2008). Urban heat island intensity in London: an investigation of the impact of physical characteristics on changes in outdoor air temperature during summer. Solar Energy 82, 986-998.

19. Giridharan, R., Lau, S.S.Y., Ganesan, S., Givoni, B., (2007). Urban design factors influencing urban heat island intensity in high rise high density environments of Hong Kong. Building and Environment 42 (10), 3669-3684.

20. TRNSYS, (2010), The Transient Energy System Simulation Tool, http://www.trnsys.com/about.htm 


\section{LIST OF FIGURES}

Figure 1: Floor plan and internal view of the case-study building in London

Figure 2: External view and spectral characteristics of the cool roof paint for the case-study building in London.

Figure 3: Position of monitoring equipment in the buildings and the roof.

Figure 4: Measured air and surface temperature of case-study building before (June) and after (August) the application of the cool roof.

Figure 5: Measured air and surface temperature of the case-study building on two days, one in June (pre-paint period) and one in August (after-paint period) during which external temperature and solar radiation are similar.

Figure 6: Measured daytime surface temperature differences (roof temperature - internal ceiling temperature)

Figure 7: Measured daytime air temperature, external-internal difference; values are daily daytime air temperature differences before and after the application of cool roof

Figure 8: Measured and Climate controlled (solar radiation) daytime air temperature trends in the open plan office

Figure 9: Temperature distribution \& difference of experiment and model.

Figure 10 : Predicted Internal Air and Operative Temperatures for the case-study building during the summer (May-September) above 25 and $28{ }^{\circ} \mathrm{C}$

Figure 11: Predicted percentage change of cooling demand for the case-study building for two summer set-point temperatures and air change rate for the range of albedo values.

Figure 12: Predicted percentage change of heating demand for the case-study building for two winter set-point temperatures and air change rate for the range of albedo values.

Figure 13: Percentage of change in heating and cooling demand for the case-study building for a range of summer/winter set-point temperatures and albedo values with a constant air change rate of $2 \mathrm{ACH}$.

Figure 14: Percentage of change in heating and cooling demand for the case-study building for a range of summer/winter set-point temperatures and albedo values with a constant air change rate of $4 \mathrm{ACH}$.

Figure 15: Variations in heating and cooling demand by changing the albedo from 0.1 to 0.7 for various insulation levels (U-value $\mathrm{W} / \mathrm{m}^{2} \mathrm{~K}$ ) 

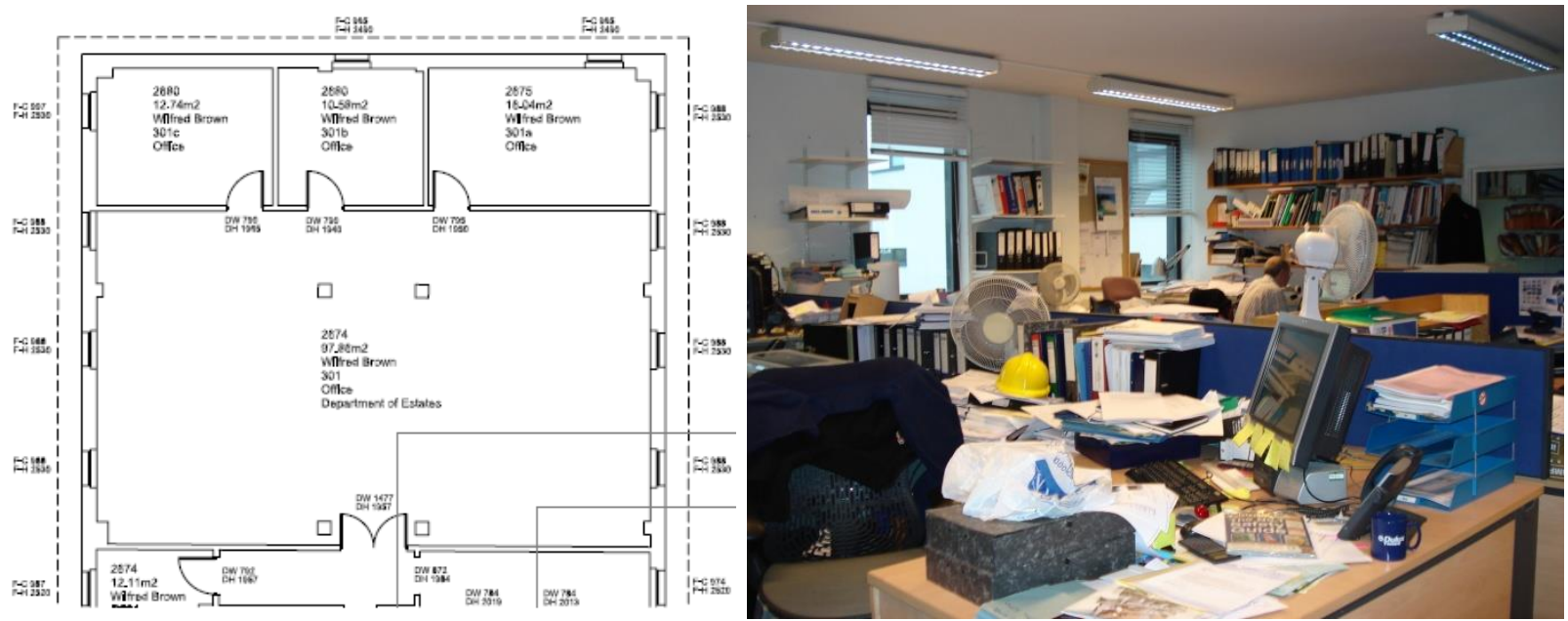

Figure 1: Floor plan and internal view of the case-study building in London

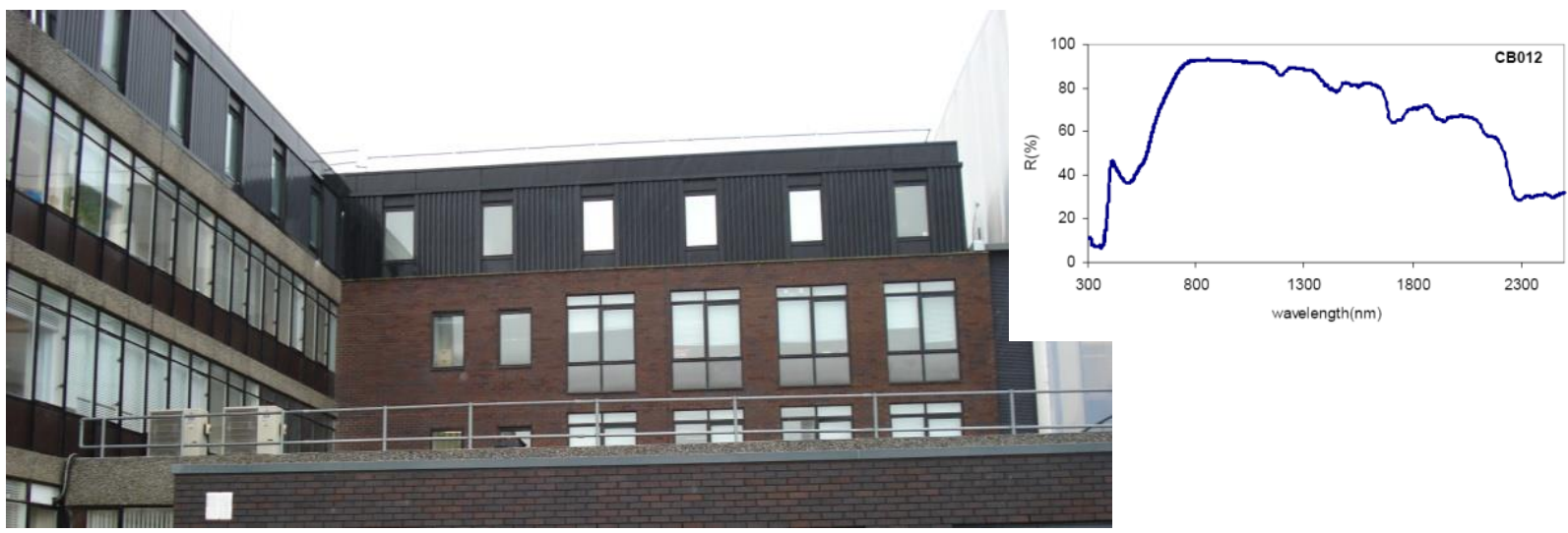

Figure 2: External view and spectral characteristics of the cool roof paint for the case-study building in London.

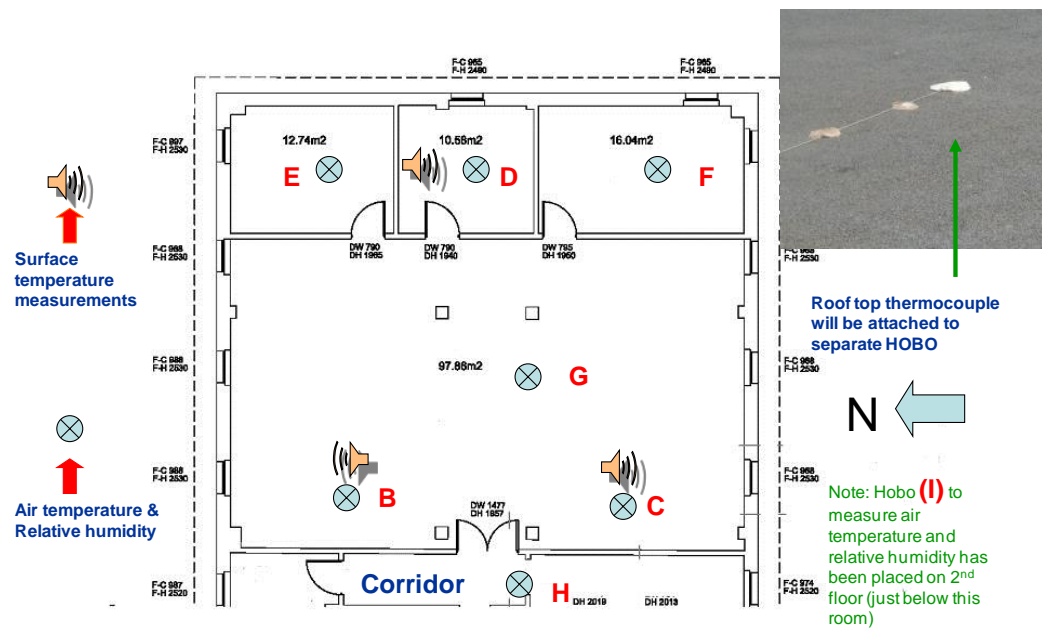

Figure 3: Position of monitoring equipment in the buildings and the roof. 


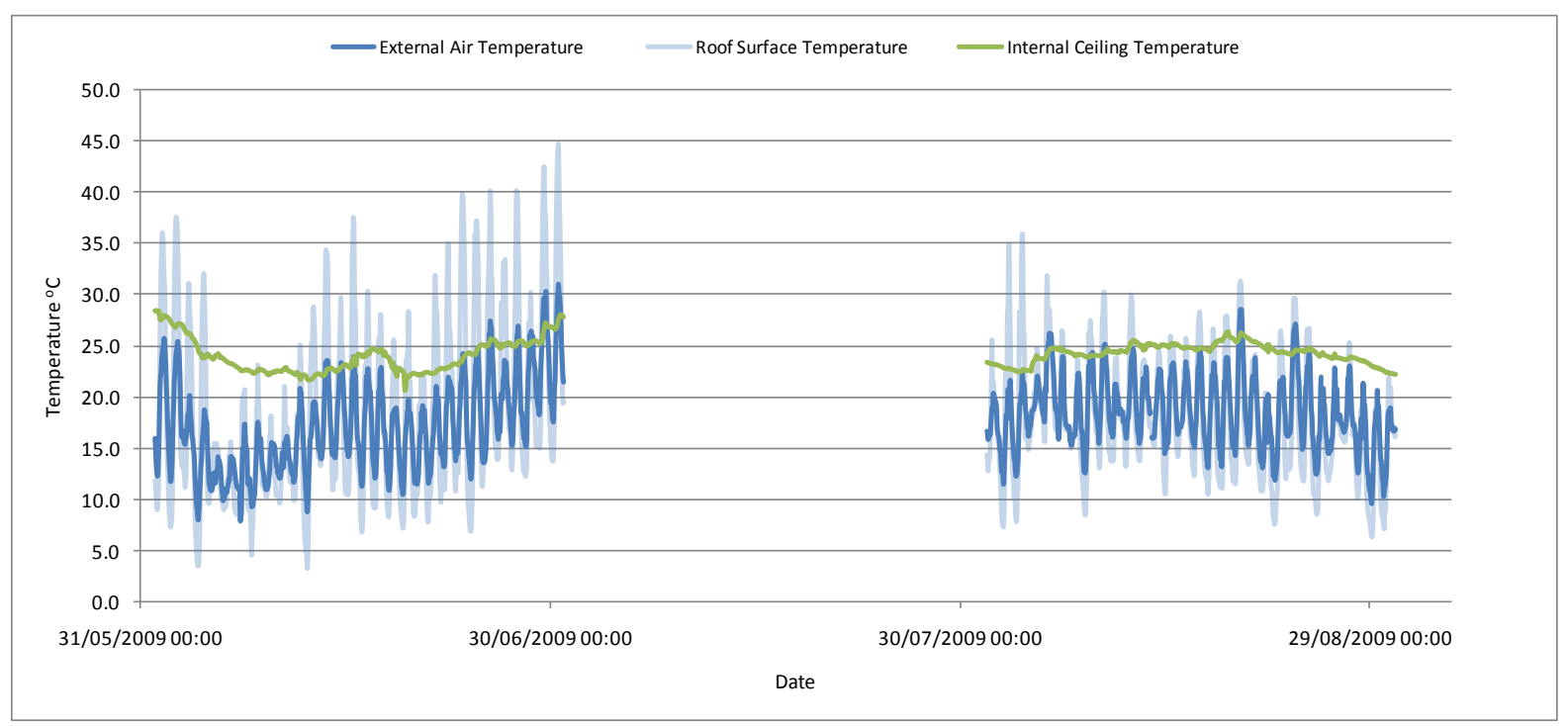

Figure 4: Measured air and surface temperature of case-study building before (June) and after (August) the application of the cool roof.

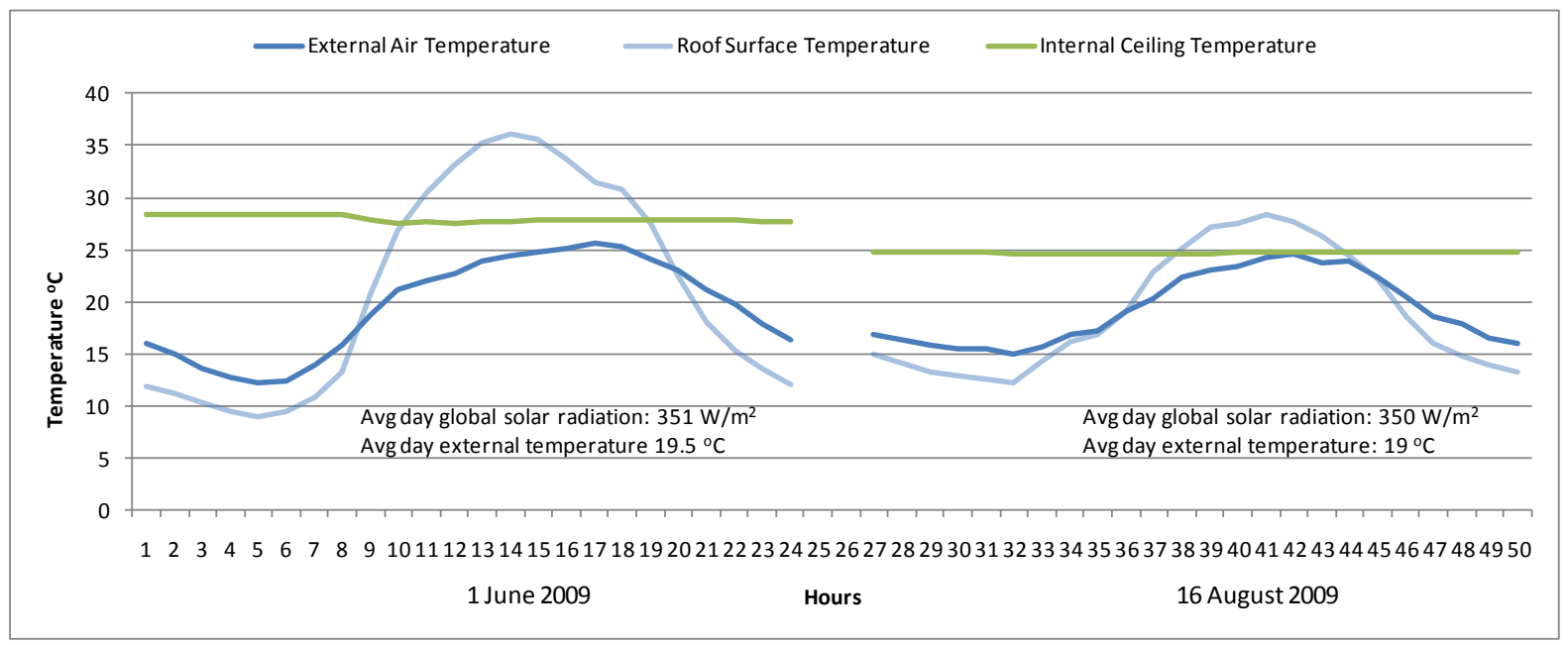

Figure 5: Measured air and surface temperature of the case-study building on two days, one in June (pre-paint period) and one in August (after-paint period) during which external temperature and solar radiation are similar. 


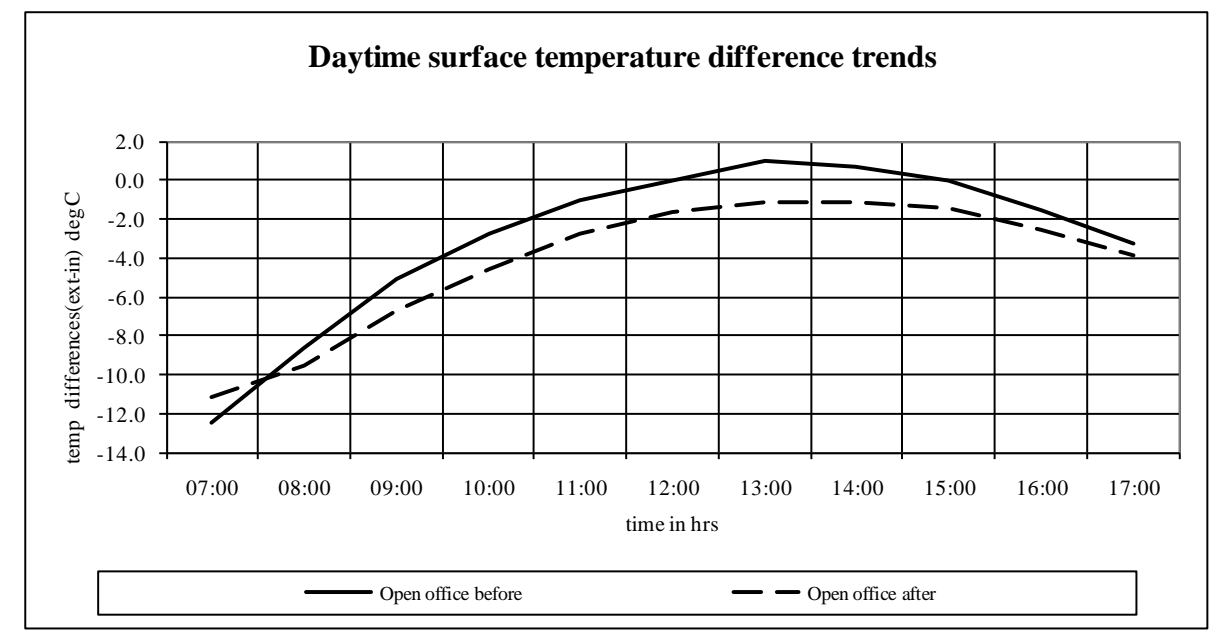

Figure 6: Measured daytime surface temperature differences (roof temperature - internal ceiling temperature)

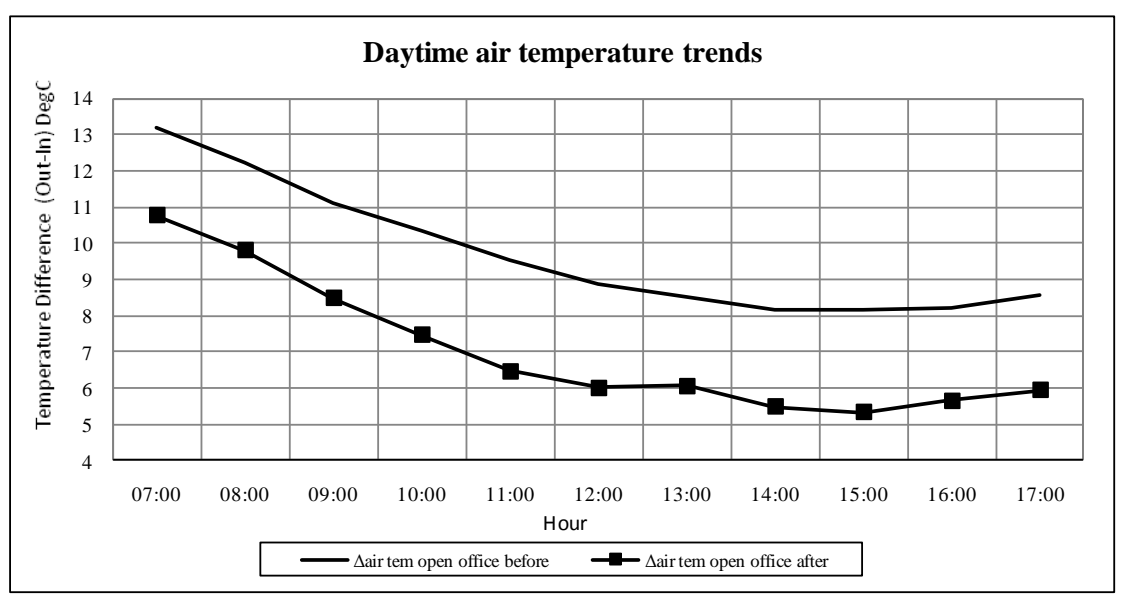

Figure 7: Measured daytime air temperature, external-internal difference; values are daily daytime air temperature differences before and after the application of cool roof 


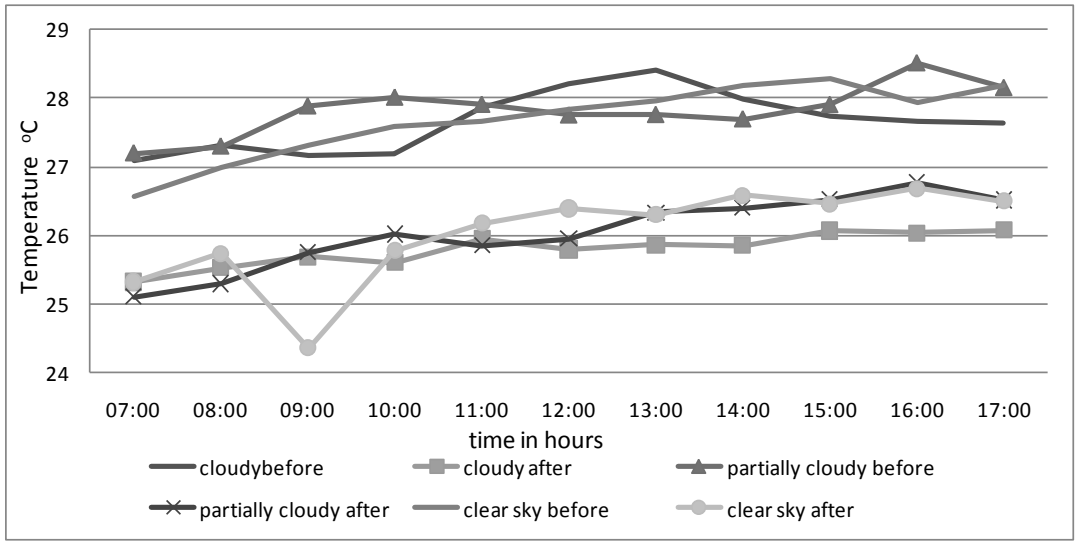

Figure 8: Measured and Climate controlled (solar radiation) daytime air temperature trends in the open plan office

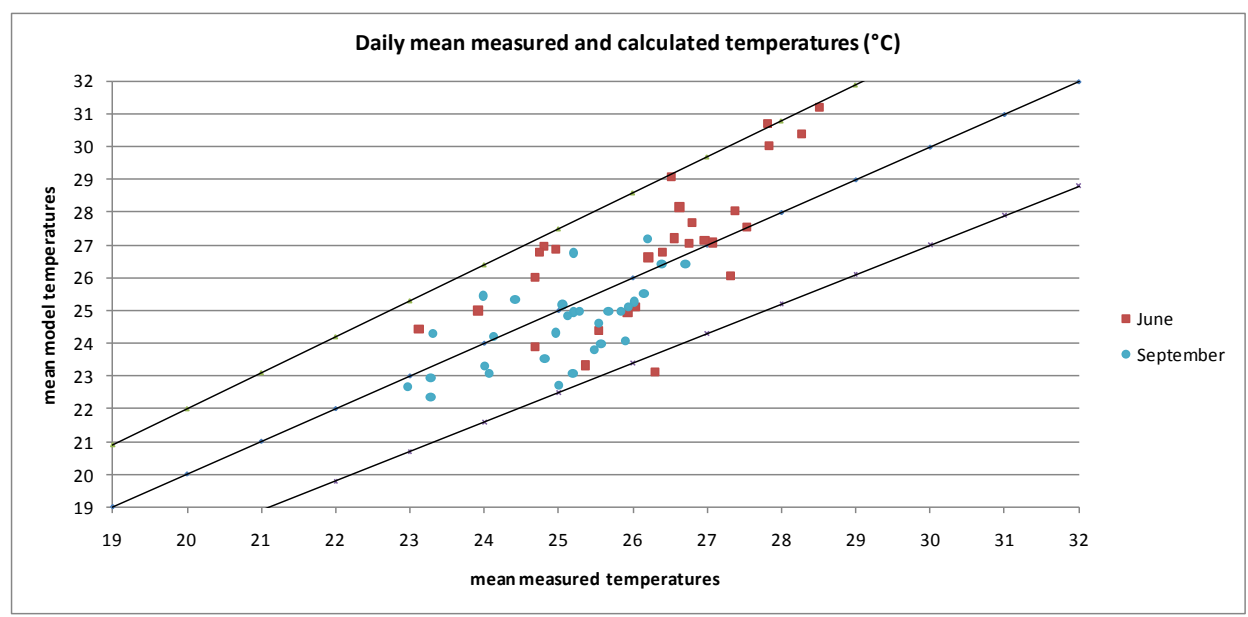

Figure 9: Temperature distribution \& difference of experiment and model. 


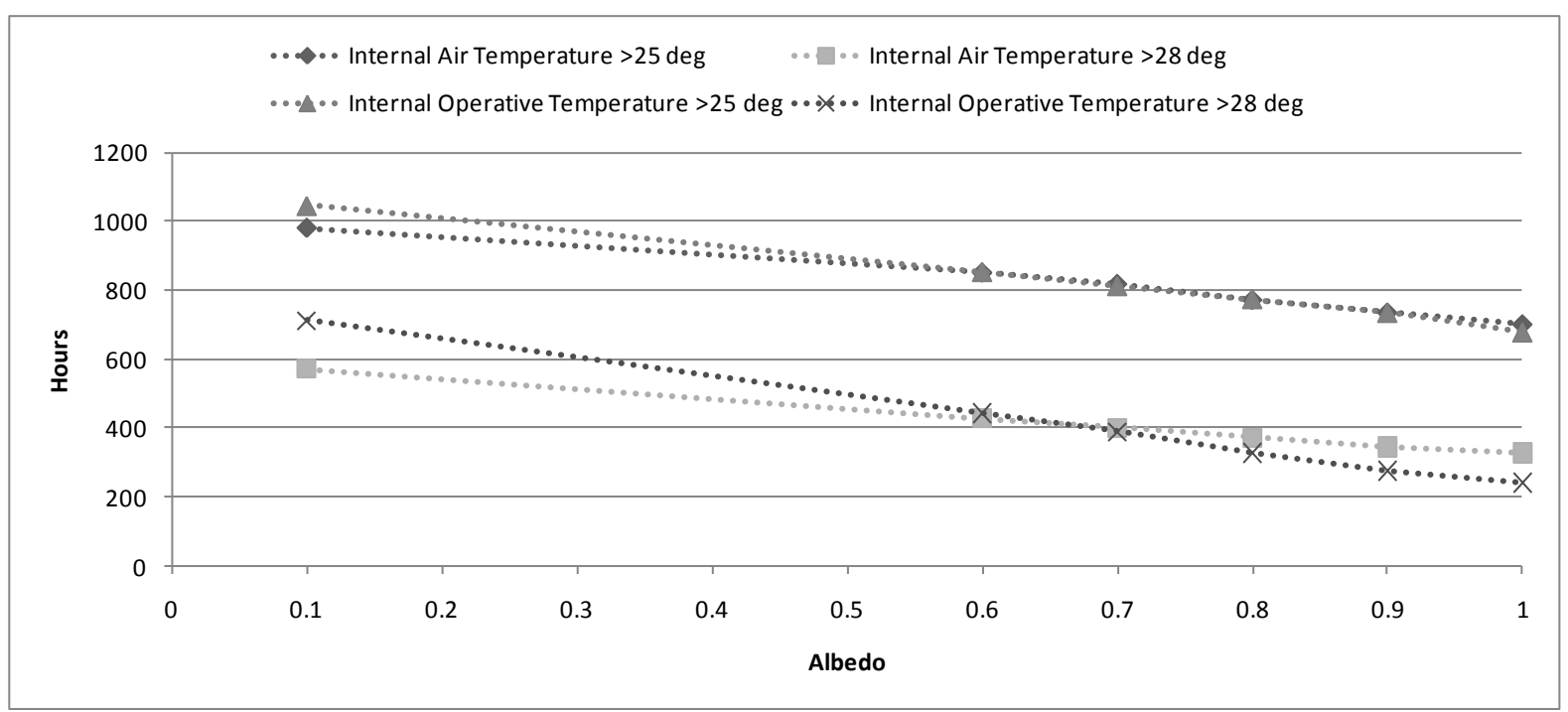

Figure 10 : Predicted Internal Air and Operative Temperatures for the case-study building during the summer (May-September) above 25 and $28{ }^{\circ} \mathrm{C}$

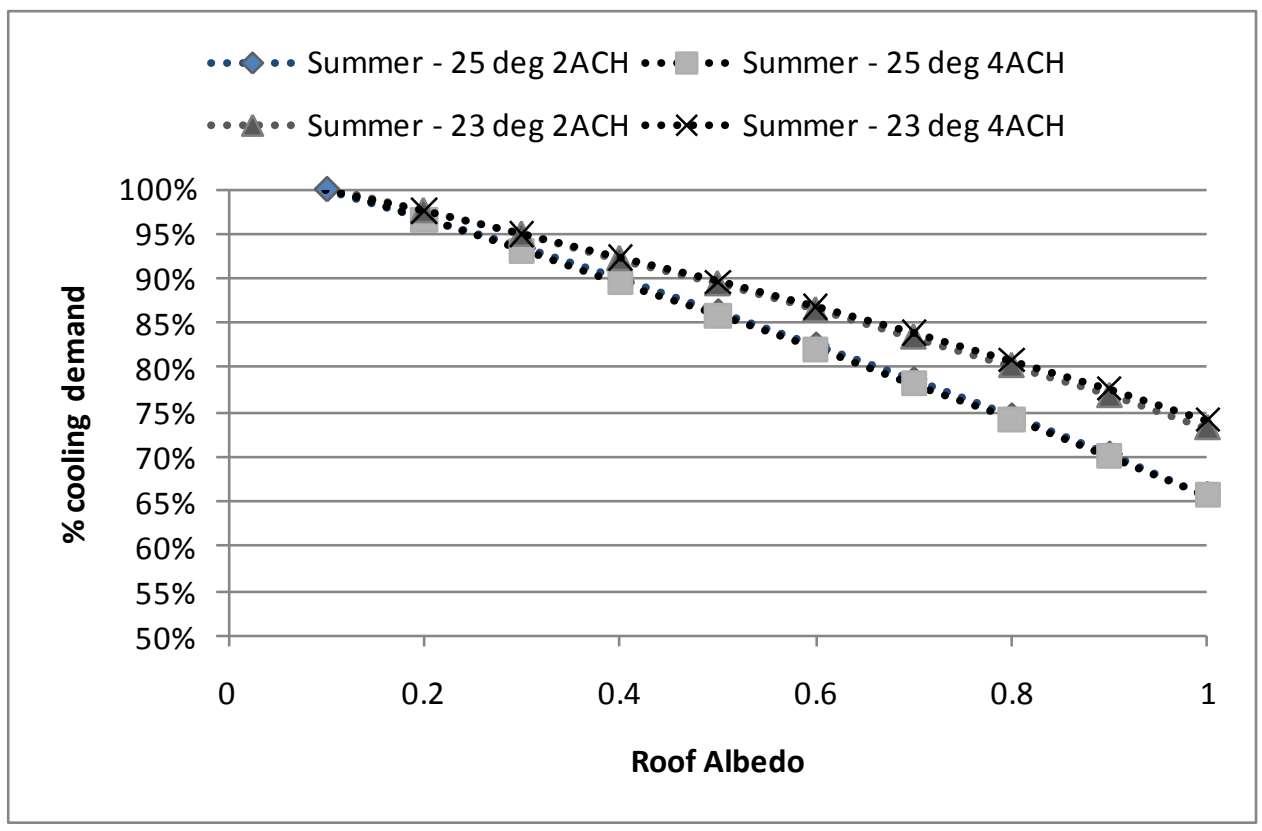

Figure 11: Predicted percentage change of cooling demand for the case-study building for two summer set-point temperatures and air change rate for the range of albedo values. 


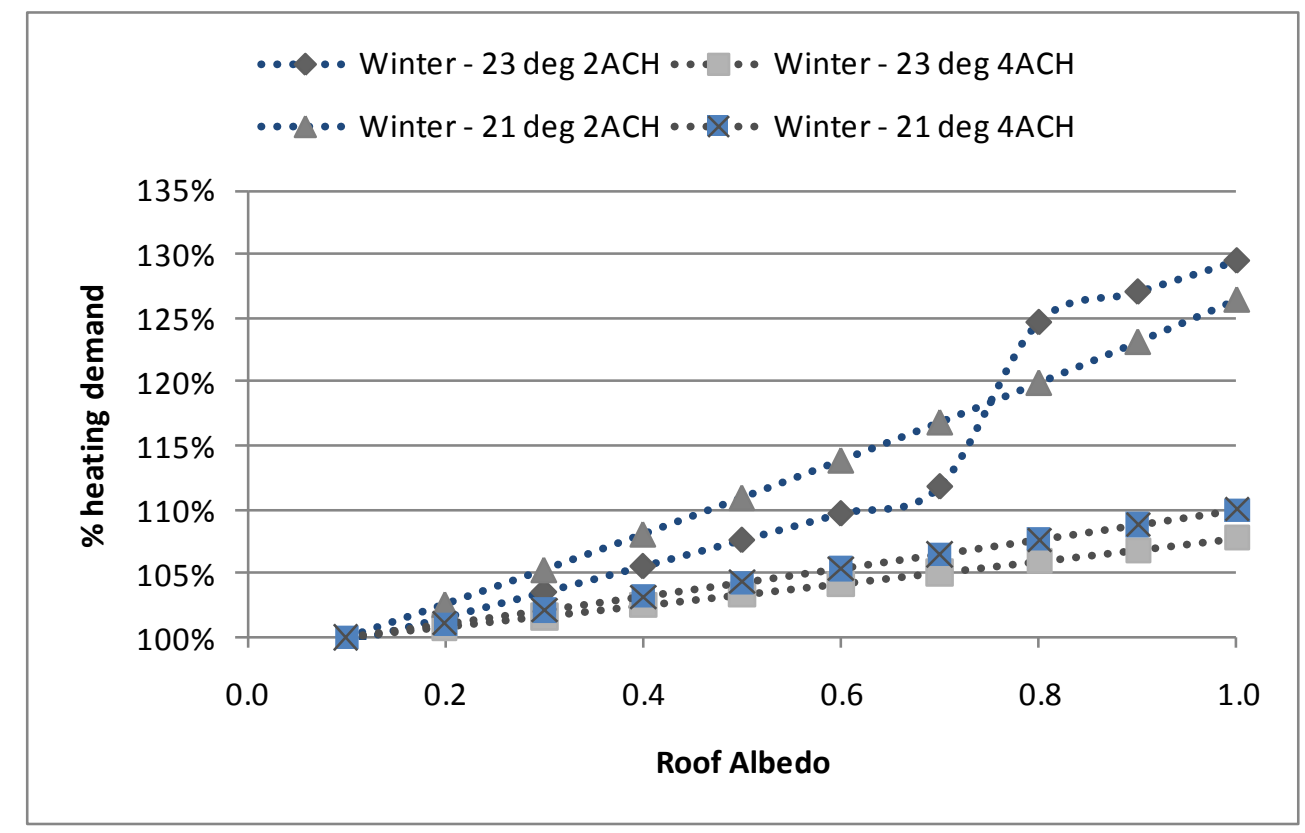

Figure 12: Predicted percentage change of heating demand for the case-study building for two winter set-point temperatures and air change rate for the range of albedo values.

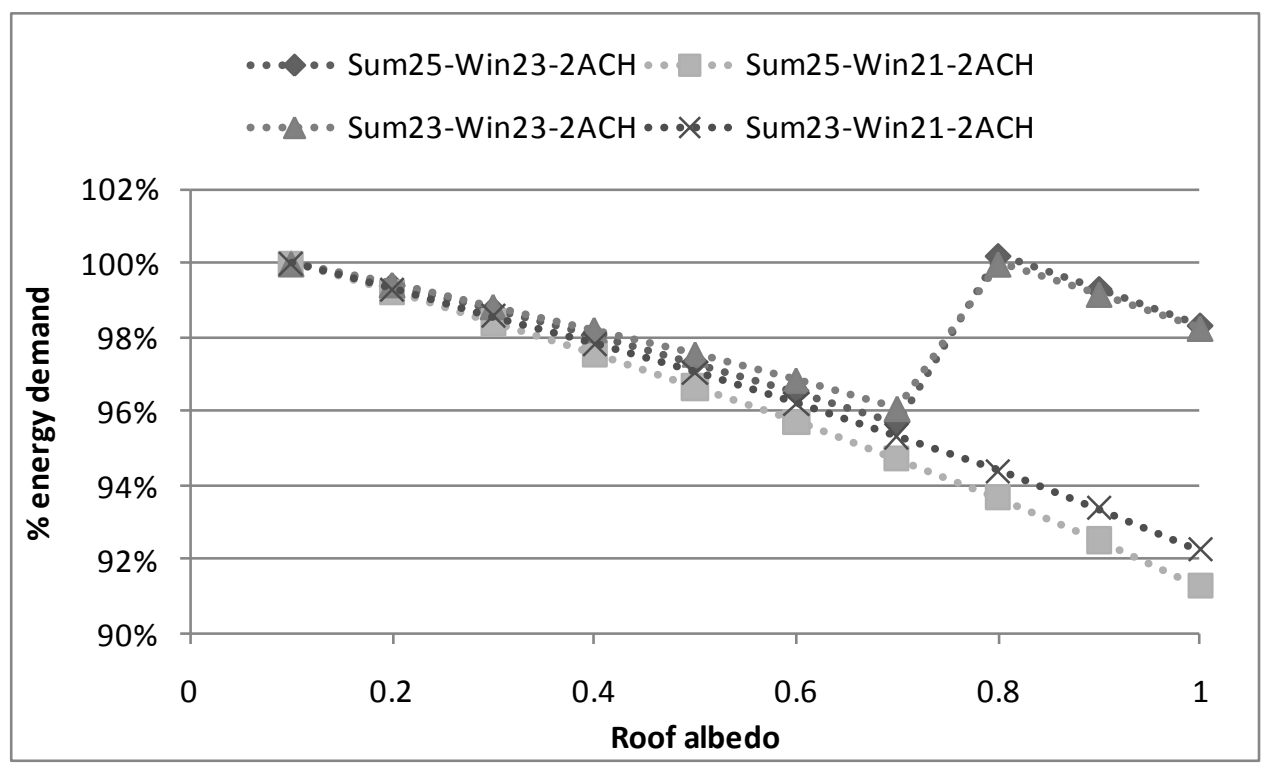

Figure 13: Percentage of change in heating and cooling demand for the case-study building for a range of summer/winter set-point temperatures and albedo values with a constant air change rate of $2 \mathrm{ACH}$. 


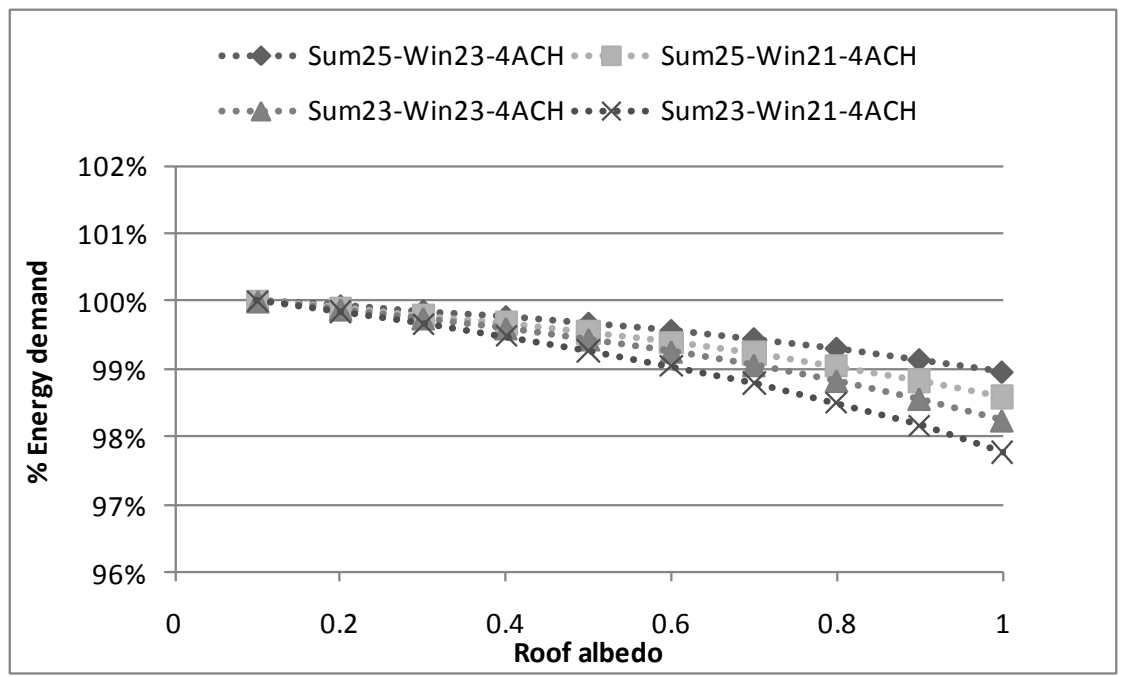

Figure 14: Percentage of change in heating and cooling demand for the case-study building for a range of summer/winter set-point temperatures and albedo values with a constant air change rate of $4 \mathrm{ACH}$.

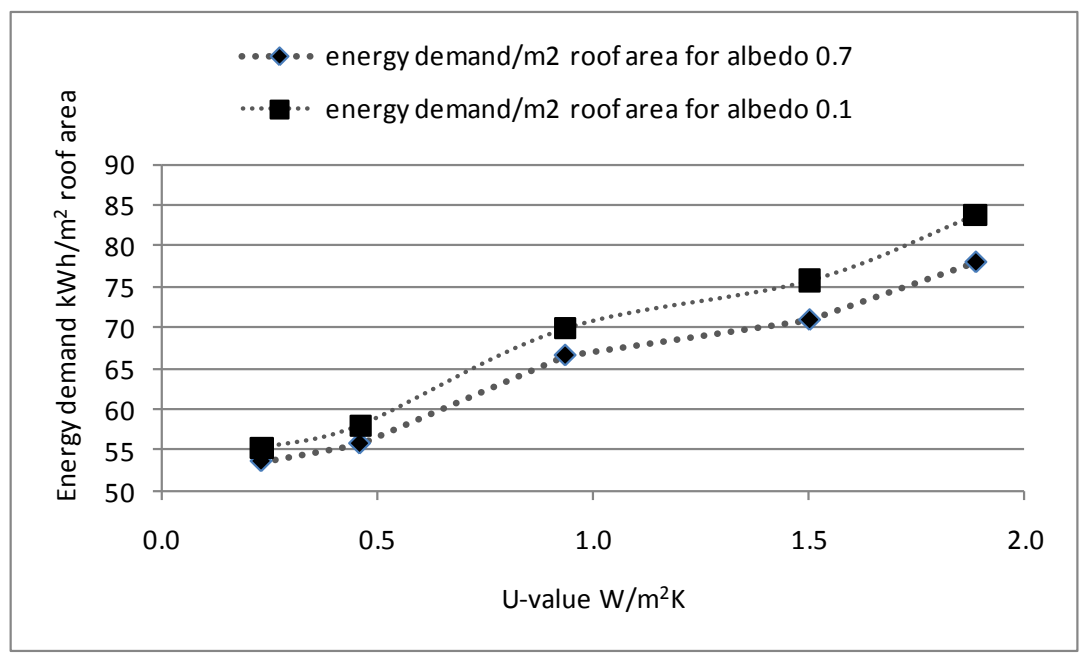

Figure 15: Variations in heating and cooling demand by changing the albedo from 0.1 to 0.7 for various insulation levels (U-value $\left.\mathrm{W} / \mathrm{m}^{2} \mathrm{~K}\right)$ 


\section{LIST OF TABLES}

Table 1: Construction and thermal characteristics of the external envelope of the case-study office

Table 2: Albedo level during clear sky period

Table 3: Internal heat gains and ventilation for the calibration model (June=pre-, Sep=after paint)

Table 4: Predicted monthly air and operative internal temperature during occupied hours

Table 5: Predicted Internal Air and Operative Temperatures for the case-study building during the summer (May-September) above 25 and $28{ }^{\circ} \mathrm{C}$

Table 6: Simulated heating and cooling energy demand for the case-study building before and after the application of the cool roof. 
Table 1: Construction and thermal characteristics of the external envelope of the case-study office

\begin{tabular}{|c|c|c|c|c|c|}
\hline & Construction & $\begin{array}{c}\text { Element } \\
\text { thickness } \\
\mathrm{m}\end{array}$ & $\begin{array}{c}\text { Total } \\
\text { Thickness } \\
\mathrm{m}\end{array}$ & $\begin{array}{c}\text { Area } \\
\mathrm{m}^{2}\end{array}$ & $\begin{array}{c}\mathrm{U}- \\
\text { value } \\
\mathrm{W} / \mathrm{m}^{2} \mathrm{~K}\end{array}$ \\
\hline External wall & $\begin{array}{l}\text { Plaster } \\
\text { Concrete block } \\
\text { Rockwool } \\
\text { Aluminium }\end{array}$ & $\begin{array}{l}0.018 \\
0.125 \\
0.18 \\
0.002\end{array}$ & 0.325 & 40.64 & 0.184 \\
\hline Internal floor & $\begin{array}{l}\text { Carpet } \\
\text { Screed } \\
\text { Concrete } \\
\text { Mineral wool } \\
\text { Plasterboard }\end{array}$ & $\begin{array}{l}0.01 \\
0.05 \\
0.15 \\
0.1 \\
0.012\end{array}$ & 0.332 & 97.6 & 0.3 \\
\hline Roof & $\begin{array}{l}\text { Plaster } \\
\text { Concrete } \\
\text { Insulation } \\
\text { Asphalt } \\
\end{array}$ & $\begin{array}{l}0.012 \\
0.12 \\
0.04 \\
0.03 \\
\end{array}$ & 0.205 & 97.6 & 0.6 \\
\hline Partitions & $\begin{array}{l}\text { Plasterboard } \\
\text { Concrete Block } \\
\text { Plasterboard }\end{array}$ & $\begin{array}{l}0.013 \\
0.215 \\
0.013\end{array}$ & 0.241 & 71.37 & 1.326 \\
\hline Glazing & $\begin{array}{l}\text { Argon filled double } \\
\text { glazing }\end{array}$ & & & & 1.4 \\
\hline
\end{tabular}

Table 2: Albedo level during clear sky period

\begin{tabular}{|l|l|l|l|}
\hline Description & Minimum & Mean & Maximum \\
\hline Before paint application & 0.06 & 0.09 & 0.14 \\
\hline After paint application & 0.28 & 0.53 & 0.83 \\
\hline
\end{tabular}


Table 3: Internal heat gains and ventilation for the calibration model (June=pre-, Sep=after paint)

\begin{tabular}{|c|c|c|c|}
\hline Parameter & Unit & Value & Schedule \\
\hline Occupancy & $\begin{array}{l}130 \mathrm{~W} / \text { person }(75 \text { sensible, } \\
55 \text { latent heat gain) }\end{array}$ & 8 persons & $\begin{array}{l}\text { Weekday 7-18 } \\
\text { Weekend none }\end{array}$ \\
\hline Equipment & $240 \mathrm{~W} /$ computer & 7 computers & $\begin{array}{l}\text { Weekday 7-18 } \\
\text { Weekend none }\end{array}$ \\
\hline Lighting & $\mathrm{W} / \mathrm{m}^{2}$ & 10 & $\begin{array}{l}\text { Weekday 7-18 } \\
\text { Weekend none }\end{array}$ \\
\hline Infiltration & $\mathrm{ACH}$ (air change per hour) & 0.4 & Continuously \\
\hline Ventilation & $\mathrm{ACH}$ & $\begin{array}{l}4 \text { in June } \\
2 \text { in September }\end{array}$ & $\begin{array}{l}\text { Weekday 7-18 } \\
\text { Weekend none }\end{array}$ \\
\hline $\begin{array}{l}\text { Roof Solar } \\
\text { Absorptance }\end{array}$ & & $\begin{array}{l}0.9 \text { in June } \\
0.4 \text { in September }\end{array}$ & Continuously \\
\hline Roof Albedo & & $\begin{array}{l}0.1 \text { in June } \\
0.6 \text { in September }\end{array}$ & Continuously \\
\hline
\end{tabular}


Table 4: Predicted monthly air and operative internal temperature during occupied hours

\begin{tabular}{|c|c|c|c|c|c|c|}
\hline \multirow[b]{2}{*}{ Albedo } & \multirow[b]{2}{*}{$\begin{array}{c}\text { Temperature } \\
{ }^{\circ} \mathrm{C}\end{array}$} & \multicolumn{5}{|c|}{ Monthly distribution of temperature } \\
\hline & & May & June & July & August & September \\
\hline \multirow[t]{4}{*}{0.6} & average air & 24.6 & 25.6 & 28.8 & 26.4 & 22.7 \\
\hline & max air & 31.2 & 33.9 & 37.2 & 33.1 & 29.6 \\
\hline & average operative & 25.1 & 26.1 & 29.2 & 26.8 & 22.7 \\
\hline & max operative & 30.5 & 32.8 & 35.4 & 31.5 & 27.5 \\
\hline \multirow[t]{4}{*}{0.1} & average air & 26.3 & 27.6 & 30.9 & 28.4 & 24.0 \\
\hline & max air & 32.5 & 35.9 & 38.5 & 34.3 & 30.7 \\
\hline & average operative & 27.1 & 28.4 & 31.7 & 29.0 & 24.3 \\
\hline & max operative & 32.8 & 34.6 & 37.6 & 33.5 & 29.2 \\
\hline
\end{tabular}

Table 5: Predicted Internal Air and Operative Temperatures for the case-study building during the summer (May-September) above 25 and $28{ }^{\circ} \mathrm{C}$

\begin{tabular}{|c|c|c|l|l|l|l|}
\hline Albedo & \multicolumn{3}{|l|}{ Internal Air Temperature ${ }^{\circ} \mathrm{C}$} & \multicolumn{2}{l|}{ Internal Operative Temperature ${ }^{\circ} \mathrm{C}$} \\
\hline & $>25^{\circ} \mathrm{C}$ & $>28^{\circ} \mathrm{C}$ & & $>25^{\circ} \mathrm{C}$ & $>28{ }^{\circ} \mathrm{C}$ & \\
\hline 0.1 & 981 & 571 & hrs & 1045 & 711 & hrs \\
\hline 0.6 & 851 & 427 & hrs & 853 & 443 & hrs \\
\hline
\end{tabular}


Table 6: Simulated heating and cooling energy demand for the case-study building before and after the application of the cool roof.

\begin{tabular}{|c|l|l|l|l|l|l|}
\hline & \multicolumn{2}{|l|}{$\begin{array}{l}\text { Heating demand } \\
\mathrm{kWh} / \text { year }\end{array}$} & \multicolumn{2}{l|}{$\begin{array}{l}\text { Cooling demand } \\
\mathrm{kWh} / \text { year }\end{array}$} & \multicolumn{2}{l|}{$\begin{array}{l}\text { Total energy demand } \\
\mathrm{kWh} / \text { year }\end{array}$} \\
\hline Albedo & \multicolumn{2}{|l|}{ Winter, set-point $21^{\circ} \mathrm{C}$} & \multicolumn{2}{l|}{ Summer, set point $25^{\circ} \mathrm{C}$} & \multicolumn{2}{l|}{} \\
\hline & $2 \mathrm{ACH}$ & $4 \mathrm{ACH}$ & $2 \mathrm{ACH}$ & $4 \mathrm{ACH}$ & $2 \mathrm{ACH}$ & $4 \mathrm{ACH}$ \\
\hline 0.1 & 1769 & 5080 & 2443 & 1758 & 4211 & 6839 \\
\hline 0.6 & 2015 & 5354 & 2017 & 1443 & 4031 & 6797 \\
\hline
\end{tabular}

